\title{
Causes of Cracks on Recently Constructed Flexible Pavements: A Case Study on Kabati to Mareira Road in Kenya
}

\author{
Benjamin K. Chamia ${ }^{1}$, Zachary Abiero Gariy ${ }^{2}$, Stephen M. Mulei ${ }^{2}$ \\ ${ }^{1}$ SMARTEC, Jomo Kenyatta University of Agriculture and Technology, Juja, Kenya \\ ${ }^{2}$ Civil Engineering Department, Jomo Kenyatta University of Agriculture and Technology, Juja, Kenya \\ Email:kithee2000@gmail.com, zagariy@yahoo.co.uk,info@jkuat.ac.ke
}

How to cite this paper: Chamia, B.K., Gariy, Z.A. and Mulei, S.M. (2017) Causes of Cracks on Recently Constructed Flexible Pavements: A Case Study on Kabati to Mareira Road in Kenya. Open Journal of Civil Engineering, 7, 177-193.

https://doi.org/10.4236/ojce.2017.72011

Received: March 7, 2017

Accepted: May 7, 2017

Published: May 10, 2017

Copyright $\odot 2017$ by authors and Scientific Research Publishing Inc. This work is licensed under the Creative Commons Attribution International License (CC BY 4.0).

http://creativecommons.org/licenses/by/4.0/

\begin{abstract}
Increased surface roughness of road due to emergence of cracks makes travelling on the road uncomfortable to road users; reduces road safety; increases wear and tear of vehicles, which push up the operating costs of vehicles, and increases travel time leading to the loss of useful man-hours to the local economy. The main objective of the study was to establish the causes of cracks on recently constructed flexible pavements with focus to Kabati to Mareira Road. To realize the study objectives, a case study was done on Kabati to Mareira road. Primary data comprising traffic count surveys; field and laboratory data for coring for compressive strength tests, tests on bearing capacity of pavement structure, and pavement deflection measurements analysis tests on improved pavement materials were undertaken on the road under study. The Secondary data on traffic axle load survey along the road under study were obtained from Kenya Rural Roads Authority, Ministry of Roads. The traffic loading was found to be 1.1 million equivalent standard axles over a design period of 15 years at a growth rate of 5\%, which is on the lower limit of T4 assumed during the design stage. The material characteristics recommended in design are sufficient for the designed traffic loading. The range of UCS values was 1.12 to $5.83 \mathrm{MPa}$ for soaked cores and 4.76 to $6.94 \mathrm{MPa}$ for un-soaked cores. The DCP results showed that subgrade has a mean CBR of $15 \%$ and a median of $14 \%$ (subgrade class S4); the sub-base has a mean CBR of $53 \%$, a range of $16 \%$ to $93 \%$ and thickness of $186 \mathrm{~mm}$ and; the base has a mean CBR of $145 \%$ a range of $20 \%$ to $433 \%$ and thickness of $137 \mathrm{~mm}$. The ratio of modulus achieved after construction for base to sub-base is 2.7:1 and 10.7:1 for the sub-base and subgrade. It is concluded that design has no aspect in development and propagation of cracks. Cracks were caused by combination of factors, namely: sub-grade does not provide sufficient support to the pavement due to high base and sub-base strengths; and the variation of strength for
\end{abstract}


pavement layers and the collapse of some cores during soaking process point to cases of inadequate/non-uniform mixing and insufficient curing of the pavement layers. Recommendation is made that the stabilizer content for base and sub-base to be varied in accordance with the properties of natural material being used based on frequency set out in standard specifications; and use of fully flexible pavements where the fill material adopted is alluvial or expansive clays. Emphasis should be placed on adequate pavement support. In improved pavement construction, the stabilizer should be uniformly distributed, thoroughly mixed and pavement layers sufficiently cured.

\section{Keywords}

Design and Construction, Flexible Pavement, Material Parameters, Pavement Cracks, Traffic Axle Loading

\section{Introduction}

\subsection{Background to the Study}

Failures of flexible pavements before their design life have been prevalent in many parts of the world. Pavement failures are caused by many reasons or combination of reasons and result from one or blend of the following pavement distresses: surface unevenness (corrugation), cracking, rutting, shoving, depression and edge dropping or breaking. Cracks, which appeared as reflective cracks or in other forms, are common signs of pavement failure and do require frequent repair treatment. Pavement failure is defined in terms of decreasing serviceability caused by development of cracks and ruts (Kumar and Gupta, 2010) [1].

When a pavement does not satisfy the design performance criteria, whether it is in terms of reduced structural capacity, increased roughness, reduced surface friction, or any other possible number of unforeseen circumstances, a premature failure has resulted. Terminal serviceability may occur sooner (in years) than anticipated; but if the pavement has carried more traffic repetitions than specified in the design, this is not premature failure; rather, this constitutes a forecasting error. The word premature implies that the actual number of years or traffic repetitions has fallen short of the anticipated design expectations. The term failure may imply more than just not satisfying the criteria under which the pavement was designed. Failure suggests that some event has occurred that affects the pavement's ability to perform its intended function of providing structural support for roadway traffic (Victorine et al., 1997) [2].

Although improvements have been made to construction specifications, equipment, and construction processes, poor quality construction can occur due to a number of complex and sometimes competing variables such as: lack of experienced inspectors and project managers; poor selection of construction materials; inadequate knowledge of the existing pavement conditions; unfamiliar construction methods and procedures; and uncertainties during design and construction phases. To reduce the probability of re-occurring premature pavement 
failures, root causes of problems need to be identified and the lessons learnt incorporated into future project designs (Chen, D. and Scullion, 2007) [3].

It has been observed that there are many roads in Kenya which have developed cracks prematurely before their design life, which may have led to pavement failures. Pavement evaluation is required to ascertain the sufficiency of design in respect to material characteristics and traffic loadings. Pavement evaluation techniques usually involve the measurement of elastic pavement surface deflections with non-destructive testing (using Dynaflect, Benkelman Beam (BB) or Falling-Weight Deflecto-meter (FWD)) combined with the back-calculation of pavement layer moduli using mechanistic-empirical based approaches, often using linear elastic theory (Konrad and Lachance, 2001) [4].

Most of roads in Kenya which have shown pavement distresses are constructed with improved or stabilized natural material forming sub-base and base with a double seal of surface dressing. A research was undertaken on the road connecting Kabati to Mareira which is located in Murang'a County in the Republic of Kenya as a case study to establish the causes of the cracks.

\subsection{Statement of the Problem}

Emergence of cracks makes travelling on the road uncomfortable to road users; reduces road safety with consequence of increased road accidents; increases wear and tear of vehicles, which push up the operating costs of vehicles; and increases travel time with consequence of loss of useful man-hours to the local economy. Bad sight of the cracked road surface create loss of aesthetics causing stresses to public and may lead to motorists diverting to other roads with consequence of loss of attraction of socio-economic development. Propagation of pavement cracks leads to the progressive degradation of the road pavement structure. Such pavement failure before the design life of the road is loss of investment to the tax payers and would require more resources for rehabilitation, repair or complete re-construction of the failed section of the road. It is therefore of vital importance to investigate and establish the causes of these premature pavement cracks so as to prevent future occurrence of such by eliminating the causes in future design and construction work.

\subsection{Objectives of the Study}

1) Determine the adequacy of the design parameters and material characteristics used in designing the flexible pavement of the road.

2) To assess the material strength characteristics of the cracked flexible pavement.

3) To establish the factors contributing to cracks in freshly constructed flexible pavements with focus to Kabati to Mareira Road.

\section{Literature Review}

\subsection{Adequacy of Design Parameters}

The structural significance of asphalt layer is small in pavements with thin as- 
phalt layer compared to that of the underlying structure and it is therefore vital that design and maintenance of such pavements, which are common in South Africa, should take this fact into account. Given the dominant role of the subgrade and of unbound aggregates in many such structures, it is clear that the principals of soil mechanics, which govern the mechanical properties of these materials, should be applied. Traditionally, the design of pavements has been dominated by empirical rules based on experience. Developments over the past 50 years or so have seen the establishment of theoretical frameworks for design and a gradual understanding of the mechanical properties of paving materials. Today's practice tends to combine theory with empiricism, the relative influence of each depending on the sophistication of the job and the resources available (Brown, 2004) [5].

The porous pavement system is often designed according to empirical procedures, which simply recommend default material proportions and pavement thicknesses, without considering the variations in climate, traffic loading, and material properties (Wang, Y and Wang, 2011) [6].

It has been observed that the two environmental parameters which influence pavement performance are temperature and moisture. Temperature conditions for a particular site have to be known to properly design an asphalt pavement or overlay. The effects of air and water on deterioration of asphalt mixtures, continues to present a challenge on durability of the pavement (Kaloush and Witczak, 2000) [7].

\subsection{Material Strength Characteristics}

Density criterion for base materials is the most common practice in quality control and quality assurance for pavement construction. However, cases in which the base material has met the density requirement but turned out to be the cause of a premature failure exist. It means meeting the density requirements would not prevent the premature failures from occurring. Field studies indicate that these base materials are found to be either too weak to provide sufficient base support or too brittle, which causes cracks in base layers which in turn leads to secondary damage in other pavement layers (Chen. D et al., 2011) [8].

Reference (Brown, 1997) [9] states that the need to incorporate the principles of soil mechanics more effectively in the design and evaluation of pavement foundations has been identified as paramount; the continued extensive use of the California Bearing Ratio (CBR) concept is questioned; and the need for application of more relevant parameters encouraged.

Cement stabilization of granular base course has been used in the road engineering field for decades to improve the mechanical properties of base course layers. Overtime, the addition of cement to granular aggregates has become widely used in the rehabilitation of low volume roads as well as heavy industry and primary highways in Canada (Berthelot et al., 2010) [10]. Lime treatment, which is a widely used method for stabilizing soils for road construction, is ineffective in certain types of clayey soils mainly due to complex reactions of stabi- 
lizer with the montmorillonite clay mineral (Fratta et al., 2010) [11]. Many roads constructed on expansive clay sub-grade especially in the east and central Texas, USA, though designed with various chemically treated soil layers, still experienced severe pavement cracking with short serviceability life periods. The costs of maintenance, in some cases, are even more than their construction costs (Chen, F, 1988) [12].

\subsection{Traffic Intensity}

According to (Praveen, 2004) [13], traffic is the most important factor influencing pavement performance. The performance of pavements is mostly influenced by the loading magnitude, configuration and the number of load repetitions by heavy vehicles. The damage caused per pass to a pavement by an axle is defined relative to the damage per pass of a standard axle load, which is defined as the equivalent $80 \mathrm{kN}$ single axle load (E80) factor. Thus a pavement is designed to withstand a certain number of equivalent axle load repetitions (E80's) that will result in a certain terminal condition of deterioration.

\subsection{Moisture (Water)}

Moisture can significantly weaken the support strength of natural gravel materials, especially the subgrade. Moisture can enter the pavement structure through cracks and holes in the surface, laterally through the subgrade, and from the underlying water table through capillary action. The result of moisture ingress is the lubrication of particles, loss of particle interlock and subsequent particle displacement resulting in pavement failure (Norman, 2009) [14].

\subsection{Subgrade}

The subgrade is the underlying soil that supports the applied wheel loads. If the subgrade is too weak to support the wheel loads, the pavement will flex excessively which ultimately causes the pavement to fail. If natural variations in the composition of the subgrade are not adequately addressed by the pavement design, significant differences in pavement performance will be experienced (Ankit, 2004) [15].

\subsection{Construction Quality}

Failure to obtain proper compaction, improper moisture conditions during construction, quality of materials, and accurate layer thickness (after compaction) all directly affect the performance of a pavement. These conditions stress the need for skilled staff and the importance of good inspection and quality control procedures during construction (David, 2006) [16].

\subsection{Summary and Research Gap}

Most of the researches undertaken on pavement cracks have been done outside Kenya under different conditions from those found in the country. These conditions include the type and quality of natural materials available for pavement construction, the level of quality control in harvesting the natural materials es- 
pecially where the quality of the materials is changing within material site or from one material site to another, method of construction and available type of construction equipment in the country. In most roads in Kenya, in-situ mixing construction method for improved or stabilized pavement is normally used whereas in other countries stationary plant mixing method is preferred. The level of road construction supervision and adherence to set design parameters in Kenya especially on drainage and compaction is an area which is different from those found in developed countries. Hence the need to assess the local Kenyan situation of determining causes of cracks on recently constructed flexible pavement.

It is therefore with the above limitations in the previous researches that this research endeavours to establish the causes of cracks on Kabati to Mareira road as a case study in Kenya to assess the local Kenya experience.

\section{Materials and Methods}

\subsection{Materials}

To realize the study objectives, a case study was done on Kabati to Mareira road. Project documentation review was conducted to form secondary data for providing basis for comparison with the current status of pavement material parameters and traffic axle loadings. Field and Laboratory investigation were also done as primary data to ascertain the current pavement design parameters in respect to traffic axle loadings and material characteristics.

\subsection{Methods}

Current traffic axle load survey for the road project was obtained from Kenya Rural Roads Authority, Ministry of Roads, for desktop study and use in analysis. Traffic count surveys, coring for compressive strength tests, tests on bearing capacity of pavement structure and pavement deflection measurements tests on improved pavement materials were undertaken on the road under study.

\section{Data Collection}

\subsection{Review of Project Documentations}

Design traffic axle loadings; design traffic class; design sub-grade class; material mechanistic characteristics of the proposed pavement materials; design pavement structure and recorded climate of the project area during the design period were obtained from the design Engineer's report. This was sourced from Kenya Rural Roads Authority, Ministry of Roads. The data was for comparing the design parameters and material characteristics with the current situation on the road under study and determine whether or not the design was adequate.

\subsection{Traffic Surveys}

Traffic count for all vehicle classes was done at one location, at Kamunyoka junction. This location was chosen as it captures traffic through the main road D416, where most cracks were observed. The vehicular traffic was measured as 
Average Daily Traffic, which is the total traffic volume during a given time period in whole days greater than one day and less than one year, divided by the number of the days in that time period.

As recommended by Chief Engineer (1987) [17], the average equivalent factors for commercial vehicles in the category of other bitumen roads were used. Cumulative equivalent standard axles were then computed and one-directional cumulative traffic flows converted to the cumulative equivalent standard axles (CESA) in each direction and compared with design requirements of the road (Chief Engineer, 1987) [17]. In the event that the computed CESA < design CESA then traffic axle loading is not a critical aspect in the pavement deterioration and vice versa.

\subsection{Coring for Compressive Strength Tests}

Seven cores of $150 \mathrm{~mm}$ diameters were extracted from locations pre-determined through visual survey of the road, within two $150 \mathrm{~m}$ sections with one representing a typical "distressed area" and the other representing a relatively "good area". The extraction of cores was done in accordance with ASTM D 3549 of thickness and density of pavement cores.

Pavement thickness and depth of cracks were measured from the cores. Samples for laboratory tests [unconfined (Mono-Axial) compressive strength test (UCS)] after 7 days soaking were also obtained from the cores. This method was used in order to compare the un-confined compressive strength (UCS) values of the cores from the road with UCS values for improved natural materials as stipulated in Chief Engineer (1987) [17]. The results obtained were to determine sufficiency of the cement/lime in achieving the required pavement strengths.

\subsection{Bearing Capacity of Pavement Structure}

Dynamic Cone Penetrometer (DCP) is an instrument which can be used for rapid measurement of the in-situ strength of existing pavements constructed with unbound materials. Since the pavement was intended to be unbound with cement/lime improved base, it is essential to determine strength at more points using a non-destructive method other than coring which is destructive. In-situ strength test of existing unbound pavement was done using DCP to supplement information on pavement and sub-grade strength. The tests were carried out at staggered intervals on the road section and were done up to depths of $800 \mathrm{~mm}$. Where pavement layers have different strengths, the boundaries between them were identified and the thickness of each layer estimated using this method. DCP tests are useful in identifying road deterioration when associated with one of the unbound pavement layers.

A comparison between DCP test results from sub-sections that are failing and those that are sound quickly identified the pavement layer which caused the pavement failure. Computation of structural number (SN), modified structural number (MSN) and DCP California Bearing Ratio (CBR) reduced to soaked equivalent value were done. The layer coefficients are related to standard tests 
for the pavement materials and are fully described in the AASHTO Guide for Design of Pavement Structures (1993). The modified structural number (SNC) calculated was used to take into account variations in sub-grade strength (Hodges et al., 1975) [18]. Then classification of existing pavement was done and compared with design requirements to ascertain whether they were achieved during construction.

\subsection{Pavement Deflection Measurements (FWD)}

Pavement deflection measurements using the FWD to determine the flexural rigidity of pavement layers and sub-grades were undertaken. This was to enable determination of the residual strength of the existing pavement. Deflections was used to determine in-situ material characteristics of the pavement layers to aid in evaluating load carrying capacity and overlay thickness requirements for the road. FWD measurements involve simulation of traffic axle loading by an impact and impulse load. The deflection was measured in accordance to the ASTM D4694-09 Standard Test Method (ASTM, 2013) [19] for deflection with a falling-weight-type impulse load device.

The resulting deflections were measured at the centre of the applied load and at various distances away from the load and in this case at nine consecutive points of $0,20,30,60,90,120,150,180$ and $210 \mathrm{~cm}$ (ASTM, 2013). To obtain sufficient data for statistical analysis, measurements were taken at intervals of approximately $100 \mathrm{~m}$ on climbing lanes and $500 \mathrm{~m}$ interval on normal carriageway at an offset of about $0.6 \mathrm{~m}$ (outer wheel path) from the edge of carriageway for the entire $30 \mathrm{~km}$ road, using a vehicle towed FWD.

The deflection data was analyzed using Rosy Design Software (ASTM, 2013) [19] to obtain layer moduli and overlay for homogeneous sections. Surface elastic modulus was computed from the following equation (ASTM D4694-09, 2006):

$$
E=\left(2 \times\left(1-v^{2}\right) \times F \times a\right) / D_{0}
$$

where: $v=$ Poison's ratio,

$F=$ uniformly distributed load on plate,

$a=$ radius of load plate,

$D_{0}=$ normalized central deflection $(\mu \mathrm{m})$.

The sub-grade and pavement Elastic modulus was obtained from Rosy Software analysis and layer classifications for sub-grade, sub-base and base was done at in-situ moisture conditions.

\section{Results, Analysis and Discussion}

\subsection{Traffic Surveys and Project Documents Review}

The traffic counts were carried out and the average daily traffic was computed from the data which consisted of 7-day 12-hour counts and 2-day 24-hour counts.

The average daily traffic (ADT) count based on the vehicle volumes was arrived at by computing the weighted average for all the days in the week as shown in the Table 1. 


\subsubsection{Average Vehicle Equivalence Factors}

Average Vehicle Equivalence factors for commercial vehicles for the design were obtained from Chief Engineer (1987) [17] for road classified as other bitumen roads and are as detailed in Table 2 below.

\subsubsection{Design Daily Equivalent Standard Axles}

The computation of traffic loading was based on the average equivalence factors for both directions since the road is less than $7 \mathrm{~m}$ wide as recommended by Road Design Manual Part III. The daily equivalence standard axles (DESA) was calculated by summing up product of average vehicle equivalence factors (E.F.) and the total average daily traffic (ADT) for both directions for each vehicle type. The E.F. values shown in Table 2 were used to convert ADT to DESA as presented in Table 3.

The daily equivalent standard axles are converted to cumulative equivalent standard axles (CESA) using the formula below:

\subsubsection{Cumulative Equivalent Standard Axles}

$$
\mathrm{CESA}=365 \times T \times\left((1+r)^{n}-1\right) / r
$$

where:

CESA-Cumulative equivalent number of standard axles;

$T$-Daily number of standard axles for base year;

Table 1. Average daily traffic.

\begin{tabular}{|c|c|c|c|c|c|c|c|c|c|c|}
\hline 䓟 & 总 & 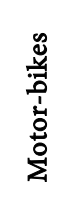 & త్ర & $\stackrel{\text { శี }}{>}$ & 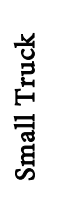 & $\stackrel{\rho}{\varphi^{\circ}}$ & 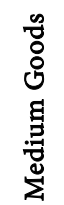 & 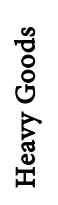 & 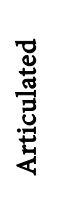 & 䒕 \\
\hline $01 / 04 / 2014$ & 243 & 1080 & 692 & 319 & 4 & 20 & 89 & 4 & 0 & 3 \\
\hline $02 / 04 / 2014$ & 278 & 1348 & 458 & 344 & 4 & 24 & 139 & 0 & 0 & 0 \\
\hline 03/04/2014 & 269 & 1152 & 365 & 416 & 4 & 12 & 105 & 1 & 1 & 1 \\
\hline 05/04/2014 & 320 & 1264 & 772 & 653 & 4 & 25 & 96 & 0 & 0 & 0 \\
\hline 06/04/2014 & 318 & 1358 & 504 & 569 & 3 & 10 & 53 & 4 & 0 & 1 \\
\hline 08/04/2014 & 294 & 1126 & 413 & 264 & 1 & 21 & 109 & 5 & 0 & 3 \\
\hline 09/04/2014 & 335 & 1610 & 673 & 710 & 4 & 41 & 97 & 3 & 0 & 0 \\
\hline TOTALS & 2057 & 8938 & 3877 & 3275 & 25 & 152 & 688 & 17 & 1 & 8 \\
\hline $\mathrm{ADT}$ & 294 & 1277 & 554 & 468 & 4 & 22 & 98 & 2 & 1 & 1 \\
\hline
\end{tabular}

Table 2. Average equivalence factors as adopted from RDM Part III.

\begin{tabular}{cc}
\hline Vehicle type & E.F. \\
\hline Bus & 1 \\
Medium Goods Vehicle & 1 \\
Heavy Goods Vehicle & 4 \\
Articulated Trucks & 4 \\
\hline
\end{tabular}


$r$-Annual traffic growth rate in expressed in decimal fraction; and,

$n$-Design period in years.

From the table above the road carries 132 Daily Equivalent Standard Axles in both directions.

A sensitivity analysis was carried out to evaluate the effect of any variation in annual traffic growth rates and various design periods. The cumulative equivalent standard axles from the analysis are presented in Table 4 below.

The traffic loading is 1.1 million equivalent standard axles (Traffic Class, T4) in accordance with Chief Engineer (1987) [17] for a 15 year period with a growth rate of 5\%, which is on the lower limit of T4 assumed during design stage.

From the above traffic analysis, it has been determined that traffic loading proposed by design engineer was adequate and therefore is not an aspect contributable to pavement cracks observed.

\subsubsection{Design Pavement Structure}

The pavement structure designed for the road was:

- Surfacing: Double surface dressing (14/20 and 6/10 mm chippings),

- Base: $\quad 150 \mathrm{~mm}$ cement \& lime improved gravel,

- Sub-base: $175 \mathrm{~mm}$ cement improved gravel, and

- Subgrade: $300 \mathrm{~mm}$ formation layer (CBR $>8 \%)$.

The pavement was designed for subgrade class S3 and Traffic class T4.

\subsubsection{Design Parameters}

The following are the main design parameters were used in designing the road:

1) Design traffic: T4 of 1.68 million Cumulative Standard Axles

2) Climate: The average annual rainfall of the whole project was above 750 $\mathrm{mm}$ and thus a classified as a wet region (mean annual rainfall $>500 \mathrm{~mm}$ ), and

Table 3. Daily equivalent standard axles on the road.

\begin{tabular}{cccc}
\hline Vehicle type & ADT & E.F. & DESA \\
\hline Bus & 22 & 1 & 22 \\
Medium Goods Vehicle & 98 & 1 & 98 \\
Heavy Goods Vehicle & 2 & 4 & 8 \\
Articulated Trucks & 1 & 4 & 4 \\
Total & & & 132 \\
\hline
\end{tabular}

Table 4. Cumulative equivalent standard axles.

\begin{tabular}{ccccccc}
\hline & \multicolumn{7}{c}{ Annual Traffic Growth Rate } \\
\cline { 2 - 7 } Design Period & $\mathbf{4 . 0 \%}$ & $\mathbf{4 . 5 \%}$ & $\mathbf{5 . 0 \%}$ & $\mathbf{5 . 5 \%}$ & $\mathbf{6 . 0} \%$ & $\mathbf{4 . 0 \%}$ \\
\hline $\mathbf{5}$ & 264,909 & 267,569 & 270,256 & 272,968 & 275,707 & 264,909 \\
$\mathbf{1 0}$ & 587,212 & 601,010 & 615,178 & 629,727 & 644,666 & 587,212 \\
$\mathbf{1 5}$ & 979,343 & $1,016,537$ & $\mathbf{1 , 0 5 5 , 3 9 6}$ & $1,095,996$ & $1,138,415$ & 979,343 \\
$\mathbf{2 0}$ & $1,456,430$ & $1,534,359$ & $1,617,238$ & $1,705,391$ & $1,799,163$ & $1,456,430$ \\
\hline
\end{tabular}


3) Available construction materials: Lateritic gravel suitable for use as cement improved sub-base and base material

From the above computed traffic class and the factual material report from the design engineer as referred in project documents review, the above design pavement structure was appropriate in respect to traffic loading, alignment soils, available construction material near the road corridor and climate. Therefore adequacy of the design parameters and material characteristics proposed during the design of the road is not an aspect in premature deterioration of the road.

\subsection{Coring}

Coring was done to ascertain base layer thickness, depth of cracks and obtain samples for laboratory testing at the various locations on the road section. Cores were extracted from the road of which three were tested in Material Testing Road Department Laboratory (MTRD) as obtained from the field and three of them were subjected to standard test for Unconfined (Mono-Axial) Compressive Test (UCS) after 7 days soak (Chief Engineer, 1987) [17] ref for test protocol? It was observed that the cracks were mostly in the base as well as the sub-base layer. Details of tests undertaken on cores are as shown in Table 5 below.

The average UCS value for the un-soaked cores on Kabati Mareira section is 5.64 MPa while that of the soaked cores is 3.1 MPa. The UCS values were above 1.2 MPa for attributed to cement improved material of base quality (Chief Engineer, 1987) [17] except for the soaked core extracted at 6+125LHS. Five out of the seven cores had base UCS values above 1.8 MPa specified UCS for cement stabilized base. The range of UCS values was 1.12 to $5.83 \mathrm{MPa}$ for soaked cores and 4.76 to $6.94 \mathrm{MPa}$ for un-soaked cores, indicating inconsistencies in the mix and highly rigid sections.

Table 5. Coring results on Kabati - Mareira section.

\begin{tabular}{|c|c|c|c|c|c|c|}
\hline $\begin{array}{l}\text { Chainage } \\
(\mathrm{Km})\end{array}$ & $\begin{array}{l}\text { Offset from } \\
\text { edge }(\mathrm{m})\end{array}$ & $\begin{array}{l}\text { Thickness } \\
\text { (mm) }\end{array}$ & $\begin{array}{c}\text { Layer } \\
\text { description }\end{array}$ & $\begin{array}{l}\text { Load } \\
(\mathrm{kN})\end{array}$ & $\begin{array}{l}\mathrm{UCS} \\
(\mathrm{MPa})\end{array}$ & Remarks \\
\hline $2+950$ LHS & 1.5 & $\begin{array}{c}20 \\
146\end{array}$ & $\begin{array}{c}\text { Surfacing } \\
\text { Base }\end{array}$ & 37.4 & 4.76 & Longitudinal crack, dry UCS \\
\hline $6+125$ LHS & 1.4 & $\begin{array}{c}18 \\
138\end{array}$ & $\begin{array}{c}\text { Surfacing } \\
\text { Base }\end{array}$ & 8.8 & 1.12 & $\begin{array}{l}\text { Longitudinal crack, core not } \\
\text { fully recovered, soaked UCS }\end{array}$ \\
\hline $7+375 \mathrm{CL}$ & 1.5 & 16 & $\begin{array}{c}\text { Surfacing } \\
\text { Base }\end{array}$ & & & Sealed crack, core collapsed \\
\hline $8+920$ RHS & 2.0 & $\begin{array}{l}20 \\
126\end{array}$ & $\begin{array}{l}\text { Surfacing } \\
\text { Base }\end{array}$ & 18.5 & 2.36 & $\begin{array}{l}\text { Surface fairly good with no } \\
\text { cracks, core not fully recovered, } \\
\text { soaked UCS Soaked) }\end{array}$ \\
\hline $12+500 \mathrm{CL}$ & 1.0 & $\begin{array}{c}20 \\
130\end{array}$ & $\begin{array}{l}\text { Surfacing } \\
\text { Base }\end{array}$ & 41.1 & 5.23 & $\begin{array}{l}\text { Core not fully recovered, dry } \\
\text { UCS }\end{array}$ \\
\hline 15+662LHS & 2.0 & $\begin{array}{l}20 \\
124\end{array}$ & $\begin{array}{l}\text { Surfacing } \\
\text { Base }\end{array}$ & 45.8 & 5.83 & $\begin{array}{l}\text { Core cut from fill, core not fully } \\
\text { recovered, soaked UCS }\end{array}$ \\
\hline $27+560$ LHS & 2.0 & $\begin{array}{r}16 \\
135\end{array}$ & $\begin{array}{l}\text { Surfacing } \\
\text { Base }\end{array}$ & 54.5 & 6.94 & $\begin{array}{l}\text { Core not fully recovered, dry } \\
\text { UCS }\end{array}$ \\
\hline
\end{tabular}


A sample of the cores extracted for laboratory testing is illustrated in Figure 1; Figure 2 shows a core undergoing compressive strength test; Figure 3 displays extraction process of cores on the road; and Figure 4 demonstrate part of the road surface with longitudinal cracks.

\subsection{Bearing Capacity by Dynamic Cone Penetrometer (DCP)}

The pavement has the following average parameters under in-situ conditions: subgrade has a mean CBR of $15 \%$ and a median of $14 \%$ (subgrade class $\mathrm{S} 4$ ); sub-base has a mean CBR of 53\%, a range of $16 \%$ to $93 \%$ and thickness of 186 $\mathrm{mm}$ and; base has a mean CBR of $145 \%$ a range of $20 \%$ to $433 \%$ and thickness of $137 \mathrm{~mm}$. The DCP test results and analysis are as in Table 6.

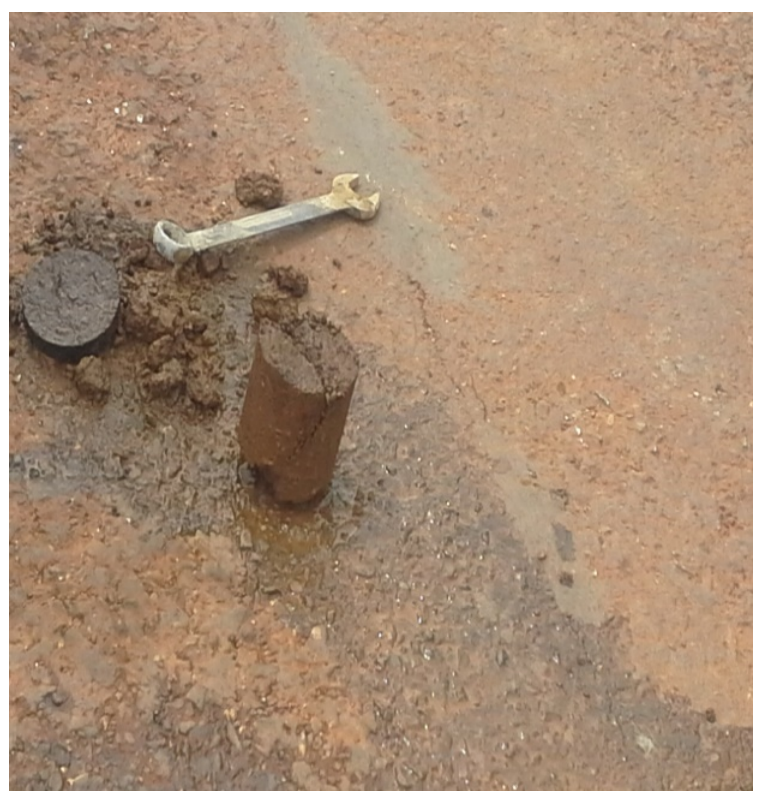

Figure 1. Core extracted from cracked section on the road.

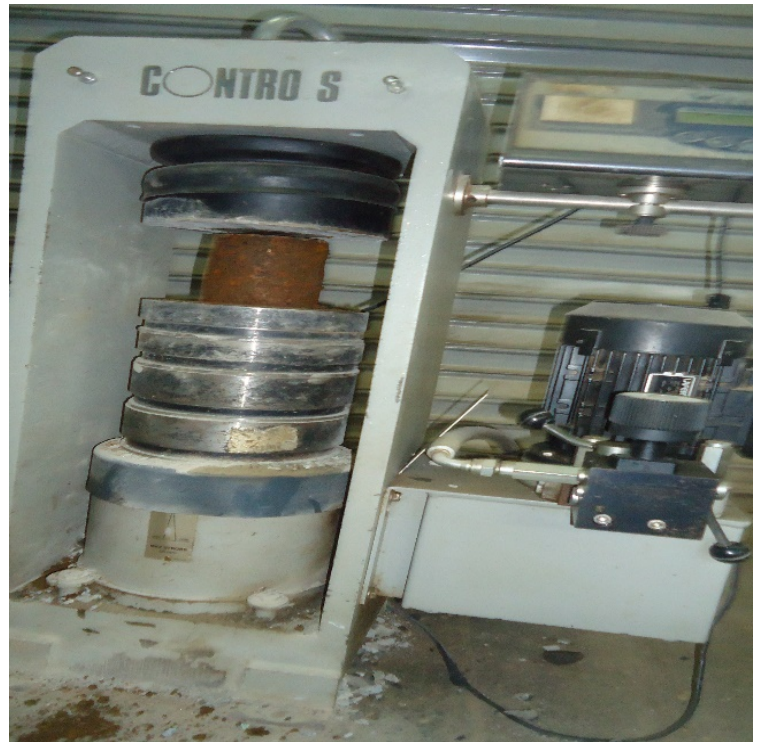

Figure 2. Compressive strength testing at MTRD on a core. 


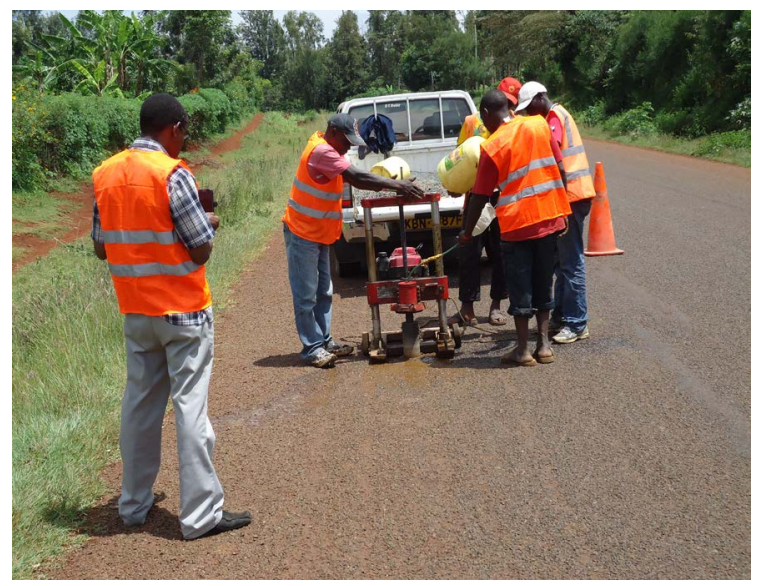

Figure 3. Core cutting on road surface.

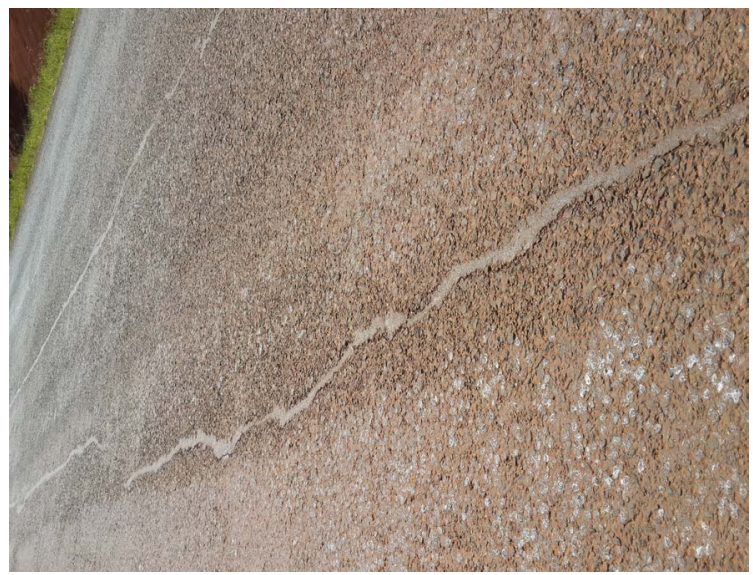

Figure 4. Sealed longitudinal cracks.

The rate of penetration for DCP when driven by a standard force is inversely related to the strength of the material, like CBR. Where the pavement layers have different strengths, the boundaries between the layers cab be identified and thickness of the layers determined. The wide range of CBRs indicates lack of uniformity in the mix and highly rigid sections.

\subsection{Pavement, Subgrade and Surface Moduli}

The deflection data was analyzed using Rosy Design Software to obtain layer moduli as shown in the Figure 5 graph.

The subgrade elastic moduli values range from 55 to $308 \mathrm{MPa}$ with an average value of $91 \mathrm{MPa}$ indicating Subgrade Class S4 at in-situ moisture condition. The lower limit of $55 \mathrm{MPa}$ indicates Subgrade Class S2. The surface and subgrade moduli profile as indicated in Figure 5 have similar pattern, as locations with high sub-grade moduli have also high surface moduli and verse versa. Moisture contents in sub-grades are prone to variation due to natural effects, including rainfall, evaporation and proximity of water table as well as material type. Every layer material has a different behavior which is largely influenced by the characteristics of the other pavement layers (Chief Engineer, 1987) [17]. This 
Table 6. DCP test results and analysis.

\begin{tabular}{|c|c|c|c|c|c|c|c|c|}
\hline Test No. & Chainage $(\mathrm{Km})$ & Base Thickness (mm) & Sub-base Thickness (mm) & Subgrade CBR & Subbase CBR & Base CBR & SN & SNP \\
\hline 1 & 1 & 199 & 213 & 49 & 33 & 40 & 0.93 & 2.96 \\
\hline 2 & 2 & 101 & 188 & 22 & 28 & 34 & 0.81 & 2.38 \\
\hline 3 & 3 & 74 & 341 & 21 & 37 & 433 & 2.11 & 3.18 \\
\hline 4 & 4 & 139 & 125 & 20 & 23 & 20 & 0.54 & 1.75 \\
\hline 5 & 5 & 167 & 80 & 19 & 34 & 50 & 0.4 & 1.39 \\
\hline 6 & 6 & 96 & 115 & 19 & 16 & 34 & 0.45 & 1.39 \\
\hline 7 & 7 & 182 & 288 & 19 & 32 & 54 & 1.07 & 2.31 \\
\hline 8 & 8 & 75 & 210 & 18 & 241 & 407 & 1.7 & 3.18 \\
\hline 9 & 9 & 146 & 185 & 17 & 89 & 183 & 2.14 & 3.56 \\
\hline 10 & 10 & 161 & 169 & 16 & 35 & 68 & 0.77 & 2.5 \\
\hline 11 & 11 & 96 & 257 & 16 & 37 & 61 & 1.18 & 2.47 \\
\hline 12 & 12 & 176 & 302 & 16 & 27 & 43 & 0.53 & 1.88 \\
\hline 13 & 13 & 108 & 107 & 15 & 46 & 77 & 1.41 & 3.22 \\
\hline 14 & 14 & 110 & 196 & 15 & 93 & 330 & 1.97 & 3.19 \\
\hline 15 & 15 & 195 & 115 & 14 & 53 & 152 & 2.35 & 4.15 \\
\hline 16 & 16 & 116 & 215 & 14 & 21 & 60 & 0.84 & 2.01 \\
\hline 17 & 17 & 193 & 189 & 13 & 42 & 255 & 2.62 & 3.77 \\
\hline 18 & 18 & 197 & 200 & 13 & 70 & 151 & 1.65 & 3.41 \\
\hline 19 & 19 & 75 & 155 & 12 & 48 & 103 & 1.4 & 3.07 \\
\hline 20 & 20 & 160 & 170 & 12 & 78 & 168 & 2.26 & 3.88 \\
\hline 21 & 21 & 165 & 198 & 12 & 66 & 269 & 1.86 & 3.45 \\
\hline 22 & 22 & 120 & 200 & 12 & 48 & 118 & 2.02 & 3.7 \\
\hline 23 & 24 & 135 & 189 & 9 & 31 & 74 & 0.93 & 2.68 \\
\hline 24 & 25 & 140 & 208 & 9 & 42 & 171 & 2.22 & 3.75 \\
\hline 25 & 26 & 138 & 215 & 9 & 71 & 180 & 1.79 & 3.46 \\
\hline 26 & 27 & 146 & 135 & 9 & 63 & 108 & 0.69 & 2.18 \\
\hline 27 & 28 & 115 & 137 & 7 & 46 & 137 & 1.7 & 3.18 \\
\hline 28 & 29 & 108 & 102 & 6 & 48 & 91 & 1.44 & 1.47 \\
\hline 29 & 30 & 153 & 179 & 2 & 52 & 348 & 2.25 & 3.65 \\
\hline Average & 15 & 137 & 186 & 15 & 53 & 145 & 1 & 3 \\
\hline
\end{tabular}

generally indicates that the subgrade has a high influence on the overall pavement strength.

Moduli of elasticity of pavement layers are as shown in the Table 7.

The elastic moduli values for subgrade range between subgrade Classes S2 to S4. The average elastic moduli values for sub-base are above the value of 300 MPa attributed to cement improved gravel for sub-base; and those for Base are above the value of $1000 \mathrm{MPa}$ attributed to base quality cement improved gravel. The first two sections of the road where there was high intensity of cracks have average elastic moduli for base exceeding the $3000 \mathrm{MPa}$, limit recommended by Chief Engineer (1987) [17] It was therefore noted that the base and sub-base 


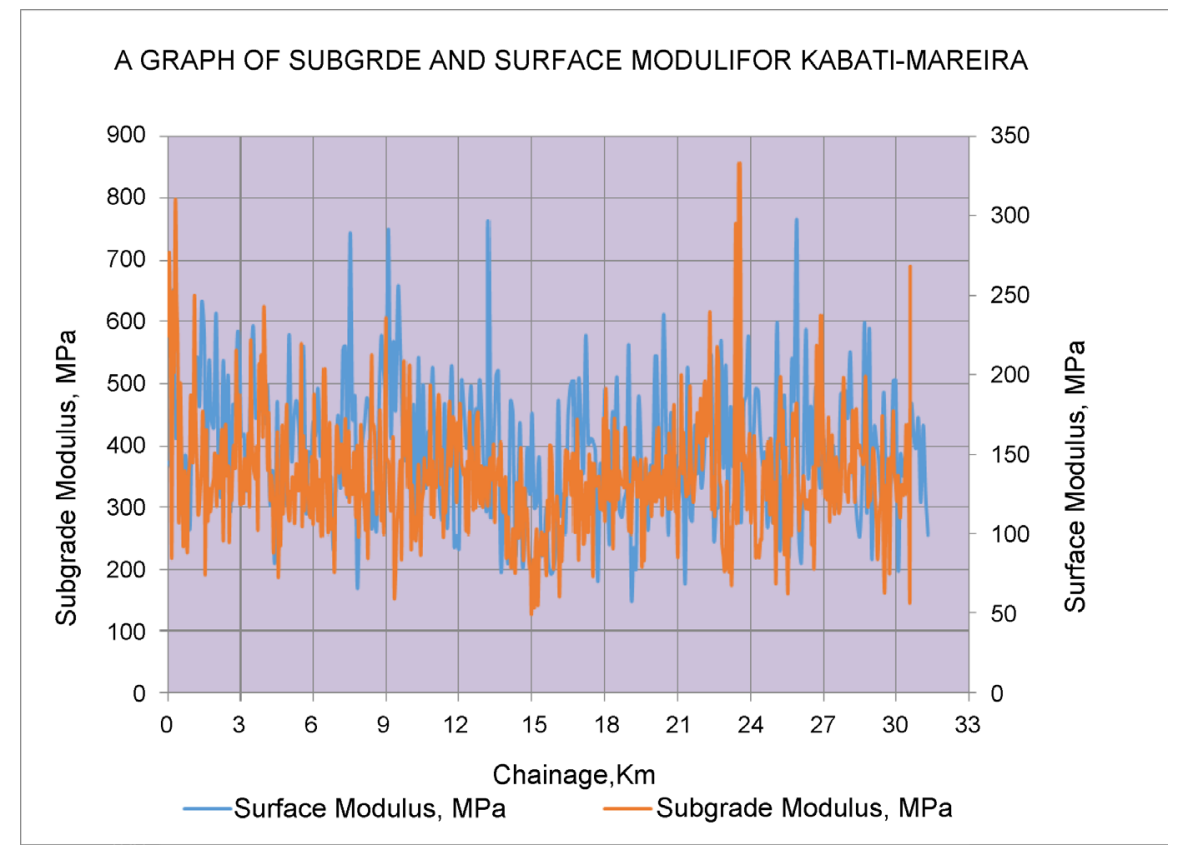

Figure 5. A graph of sub grade and surface moduli along the alignment.

Table 7. Elastic moduli, Kabati-Mareira.

\begin{tabular}{|c|c|c|c|}
\hline \multirow{2}{*}{ Homogenous section } & \multicolumn{3}{|c|}{ Elastic Modulus, $\mathrm{E}_{\mathrm{m}}(\mathrm{MPa})$} \\
\hline & Base & Sub-base & Subgrade \\
\hline $\mathrm{Km} 0+000-\mathrm{Km} \mathrm{3+100}$ & 3653 & 728 & 95 \\
\hline $\mathrm{Km} \mathrm{3+100-Km} \mathrm{13+500}$ & 3050 & 591 & 100 \\
\hline $\mathrm{Km} 13+500-\mathrm{Km} \mathrm{16+400}$ & 1802 & 1115 & 86 \\
\hline $\mathrm{Km} 16+400-\mathrm{Km} \mathrm{17+600}$ & 2938 & 847 & 88 \\
\hline $\mathrm{Km} 17+600-\mathrm{Km} 21+300$ & 2343 & 1354 & 89 \\
\hline $\mathrm{Km} 21+300-\mathrm{Km} 32+000$ & 1847 & 1216 & 87 \\
\hline Average $\mathrm{E}_{\mathrm{m}}(\mathrm{MPa})$ & 2606 & 975 & 91 \\
\hline
\end{tabular}

were constructed to higher strengths than necessary for flexible pavement, that is, modulus $2606 \mathrm{MPa}$ and $975 \mathrm{MPa}$ as compared to $1000 \mathrm{MPa}$ and $300 \mathrm{MPa}$ assumed in design, respectively. The average elastic moduli for both base and sub-base exceed the specified tolerances for scatter, that is, $\pm 30 \%$ (700 to 1300 MPa for base and 210 to $390 \mathrm{MPa}$ for sub-base (Chief Engineer, 1987) [17].

\section{Summary of Findings}

\subsection{Conclusions}

The pavement design of the road was found to be sufficient as the forecast traffic axle loadings for a design period of 15 years was less than class T4 used to design the pavement structure. The material characteristics recommended in design were sufficient for the design traffic loading. Therefore the design has no aspect in development and propagation of the cracks.

The base and sub-base layers have adequate strength but the values of moduli 
are in some sections higher than recommended for a flexible pavement, leading to semi-rigid pavement overlying flexible subgrade. Therefore the subgrade does not provide sufficient support to the pavement due to the high base and sub-base strength. The variation of strength for pavement layers; the average elastic moduli for both base and sub-base exceed the specified tolerances for scatter, and the collapse of some pavement cores during soaking process point to inadequate/non-uniform mixing and insufficient curing of the pavement layers. Therefore, pavement cracks were caused by combination of factors, namely: sub-grade does not provide sufficient support to the pavement due to high base and sub-base strengths; and the variation of strength for pavement layers and the collapse of some cores during soaking process point to cases of inadequate/nonuniform mixing and insufficient curing of the pavement layers.

\subsection{Study Recommendations}

It is recommended that amounts of stabilizer for improving strength of pavement layers to be varied in accordance with the properties of the natural materials being used and be based on frequency set out in the standard specifications; make use of fully flexible pavements where the fill material adopted is alluvial or expansive clays; and stabilizer used to improve strength of pavement layers should be uniformly distributed, thoroughly mixed and pavement layers sufficiently cured. Emphasis should be laid on adequate pavement support. Further investigations on chemical analysis of improved natural material forming pavement and visual conditions surveys are recommended to be undertaken.

\section{References}

[1] Kumar, P. and Gupta, A. (2010) Case Studies on Failure of Bituminous Pavements. Compendium of Papers from the First International Conference on Pavement Preservation. National Library of Canada, Ottawa.

[2] Victorine, T., Zhang, A.Z., Fowler, D.W. and Hudson, W.R. (1997) Basic Concepts, Current Practices, and Available Resources for Forensic Investigations on Pavements. Center for Transportation Research Bureau of Engineering Research, The University of Texas at Austin, Austin.

[3] Chen, D.H. and Scullion, T. (2007) Forensic Investigations of Roadway Pavement Failures. Journal of Performance of Constructed Facilities, 22, 14-18.

[4] Konrad, J.M. and Lachance, D. (2001) Use of In Situ Penetration Tests in Pavement Evaluation. National Research Council, Ottawa.

[5] Brown, S.F. (2004) Application of Soil Mechanics Principles to Design and Testing of Pavement Foundations. Proceedings of the 8 th Conference on Asphalt Pavements for Southern Africa, Sun City, 12-16 September 2004.

[6] Wang, Y. and Wang, G. (2011) Improvement of Porous Pavement. US Green Building Council, Washington DC.

[7] Kaloush, K.E. and Witczak, M.W. (2000) Development of a Permanent to Elastic Strain Ratio Model for Asphalt Mixtures. Development of the 2002 Guide for the Design of New and Rehabilitated Pavement Structures. NCHRP 1-37 A, Inter Team Technical Report.

[8] Chen, D., Chang, G. and Fu, H. (2011) Limiting Base Moduli to Prevent Premature 
Pavement Failure. American Society of Civil Engineers, 25, 587-597. https://doi.org/10.1061/(asce)cf.1943-5509.0000192

[9] Brown, S.F. (1997) Achievements and Challenges in Asphalt Pavement Engineering. Proceedings of the 8 th International Conference on Asphalt pavements, Seattle, 10-14 August 1997.

[10] Berthelot, C., Podborochynski, D., Marjerison, B. and Saarenketo, T. (2010) Mechanistic Characterization of Cement Stabilization Marginal Granular Base Material for Road Construction. NRC Research Press, Ottawa.

[11] Fratta, D.O., Puppala, A.J. and Muhunthan, B. (2010) Influence of Lime Dosage on Stabilization Effectiveness of Montmorillonite Dominant Clays. American Society of Civil Engineers, Reston.

[12] Chen, F.H. (1988) Foundations on Expansive Soils. 2nd Edition, Elsevier Science Publications, New York.

[13] Kumar, P. (2004) Case Studies on Failure of Bituminous Pavements. Proceedings of the First International Conference on Pavement Preservation, Newport, 12-16 April 2010, 1-5.

[14] Norman, R. (2009) Extending Pavement Life by Forestalling Crack Reflection. Proceedings of the First International Conference on Pavement Preservation, Newport, 12-16 April 2010, 2-8.

[15] Ankit, G. (2004) Report on Case Studies on Failure of Bituminous Pavements. PWD Report, Aligarh, 1-14.

[16] David, P.O. (2006) Pavement Maintenance. Engineer Cornell Local Roads Program. Cornell Local Roads Program, 17-40.

[17] Chief Engineer (Roads and Aerodromes) (1987) Road Design Manual Part III. Ministry of Roads.

[18] Hodges, J.W., Rolt, J. and Jones, T.E. (1975) The Kenya Road Transport Cost Study: Research on Road Deterioration. TRL Research Report LR673. Transport and Road Research Laboratory, Crowthorne.

[19] Road and Paving Materials: Vehicles-Pavement Systems (2013) Annual Book of ASTM Standards, Section Four-Construction, 460.

\section{Scientific Research Publishing}

\section{Submit or recommend next manuscript to SCIRP and we will provide best service for you:}

Accepting pre-submission inquiries through Email, Facebook, LinkedIn, Twitter, etc. A wide selection of journals (inclusive of 9 subjects, more than 200 journals)

Providing 24-hour high-quality service

User-friendly online submission system

Fair and swift peer-review system

Efficient typesetting and proofreading procedure

Display of the result of downloads and visits, as well as the number of cited articles

Maximum dissemination of your research work

Submit your manuscript at: http://papersubmission.scirp.org/

Or contact ojce@scirp.org 